\title{
FDG-PET による頭頸部腫瘍診断
}

\section{Diagnosis of Head and Neck Tumor with FDG-PET}

\author{
中井茂
}

はじめに

PETによる癌診断は, 2002年4月にブドウ糖類似物質で ある Fluorine-18 2-deoxy-2-fluoro-D-glucose（FDG）を用 いた FDG-PET が保険適用となり積極的な臨床応用がも たらされた。ささざまな領域の癌診断において有用性が 報告され，頭頸部領域でも今後さらなる活用が期待され ている. FDG-PET はブドウ糖代謝能を表示する点がユ ニークで，形態の変化を捉える CT, MRI とは大きく異 なっている. また， 1 回の検査で全身の癌の検索が可能 である点も有益である．頭頸部領域での活用においては 解剖学的な理由等から, その結果の取り扱いには注意も 必要である。

\section{PET検査の実際}

頭頸部癌において，以下の場合に FDG-PET が保険適 用と規定されている.

1）ほかの検查，画像診断により癌の存在を疑うが，病 理診断により確定診断が得られない，2）ほかの検查，画 像診断により病期診断, 転移, 再発の診断が確定できな い.

検査は 4 時間以上の絶食の後, FDG を静脈内投与し 1 〜2 時間の集積時間を経てポジトロンカメラで撮像を行 う. 投与後の FDG はブドウ糖類似物質のため, 体内の ブドウ糖とほぼ同様の生理的分布を示す，糖代謝が最も 盛んである脳にはきわめて強く集積する，ほかにも糖代 謝の程度に応じて集積を認め, 心筋・筋肉・唾液腺・甲 状腺・口蓋扁桃・肝・胃・褐色脂肪などは通常高い集積 を呈す. FDG は尿路に排泄され腎・尿管・膀胱も強く描 出される.FDG はブドウ糖と同様に細胞膜表面のグル コース輸送体膜蛋白（GLUT）を介して細胞質へ取り込 まれ，ヘキソキナーゼによりリン酸化を受ける.ブドウ 糖はさらに解糖系に進むが，リン酸化された FDG は細 胞内へとどまり蓄積される. FDG の細胞内への取り込み
は血中のブドウ糖と競合するため，検查前の絶食が必要 である. FDG 投与後の安静も筋肉への取り込みを抑制し コントラストを高めるために重要である.

PET画像の評価は正常組織との視覚的コントラストを 捉えるか, 半定量的評価方法を用いる。後者には standardized uptake value（SUV）が頻用され，組織放射 能カウント $(\mathrm{cpm}) /$ 組織重量 $(\mathrm{g})$ と総放射能カウント $(\mathrm{cpm}) /$ 体重 $(\mathrm{g})$ の比で表現される. SUV $>2 \sim 2.5$ の 集積部が悪性腫瘍の疑いと診断される.

癌に FDG が高集積する機序は GLUT の過剩発現，へ キソキナーゼの活性の充進によると考えられている，糖 代謝の低い癌や，壊死や囊胞化のため細胞成分が少ない 癌では偽陰性となり FDG-PET で捉えることは困難であ る。また，生理的な FDG 集積部位，集積がみられる良 性腫瘍（脳，唾液腺，甲状腺など）, 炎症性疾患への集積 （膿瘍，サルコイドーシス，橋本病，扁桃炎など）による 偽陽性の可能性にも留意する必要がある.

\section{頭頸部癌診断}

FDG-PETによる頭頸部癌原発巣の描出率は $90 \%$ 以上, 転移リンパ節の検出も敏感度, 特異度ともに $90 \%$ 前後と の報告が多く，鋭敏さでほかの画像診断による精度を凌 ぐとされる. 原発不明癌の原発巣の同定, 再発巣の精查, 病期分類の決定，リンパ節転移の精査，化学療法・放射 線治療の効果判定に臨床応用されている.

頭頸部癌の診断においては以下の点で注意が必要であ る.1）唾液腺, 筋肉, 扁桃など生理的集積部位が多数箇 所存在, 2) 頭頸部は解剖学的に複雑であり, 小病変の同 定が困難，3）放射線・抗癌剂治療の影響.

以上から早期癌や小さな癌病巣を FDG-PET 単独で診 断するには注意が必要で，正確な診断のためにはほかの 画像診断と比較検討することが望ましい. PET と CT を 同一機器で撮影でき，両者の情報を正確に重ね合わせて 

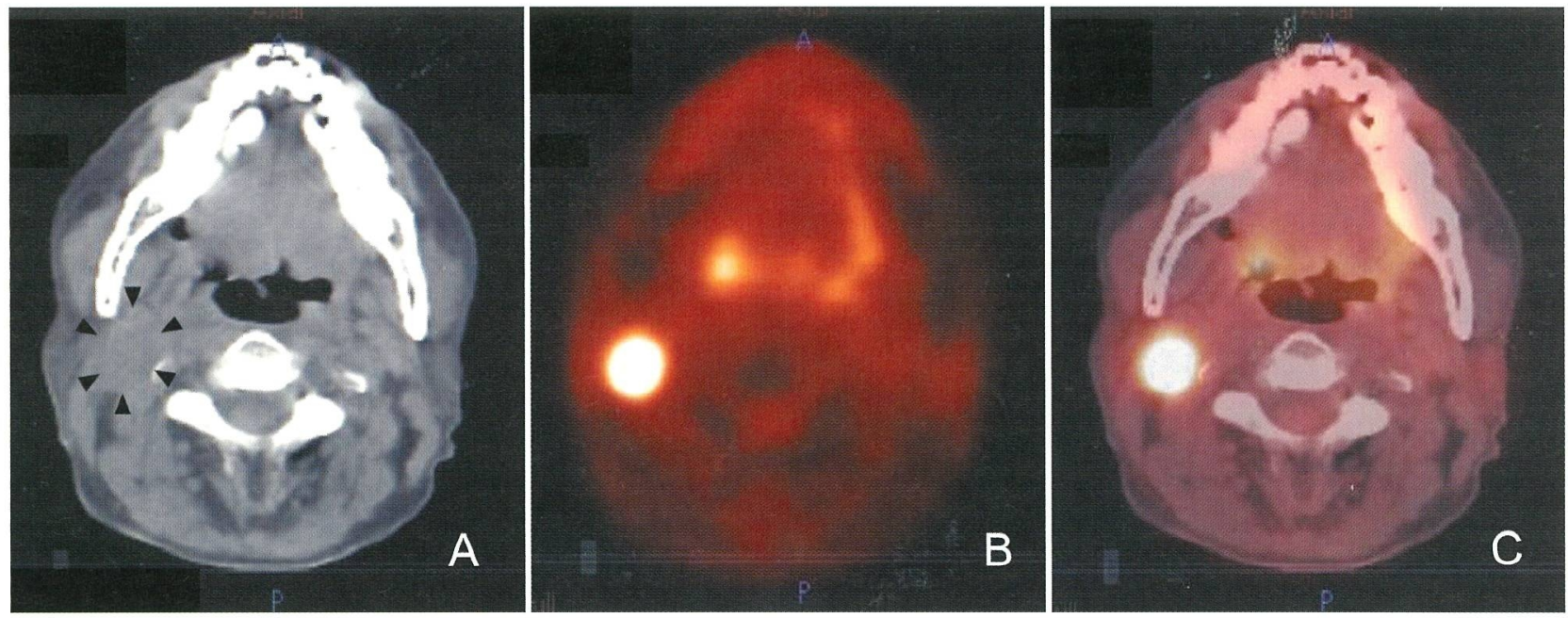

図 1 右中咽頭癌（側壁型）T2N1M0 放射線治療後の PET/CT fusion 画像

A：CT 画像. 右上内深頸領域にリンパ節腫脹を認める (矢頭)。

B：FDG-PET 画像。右頸部に異常集積と, 右中咽頭付近に中程度の集積を認める. 空間分解能は低い。

C : PET/CT fusion 画像. CT でみられるリンパ節に一致して FDGの高集積を認める. 中咽頭付近の集積部位は口蓋扁桃と判明し た。生検にて口蓋扁桃には癌の残存はみられなかったが，FNA で頸部リンパ節に転移が確認された。

表示 (fusion imaging)（図 1) する PET/CT 装置が有益で ある。

抗癌剤・放射線治療後に残存した癌細胞への FDG の 集積は一般には低下するが，腫瘍壊死に関連した炎症細 胞へも FDG が集積する.ホジキン病において1〜2 クー ルの抗癌剤治療後, SUV が $60 \%$ 以上減少する例は予後良 好であったと報告されている11。放射線治療後の炎症の ため数力月間 FDG の集積を認めた大腸癌症例の報告 ${ }^{2)}$ もあり，癌の残存，再発との鑑別には数力月から6力月 以上の期間が必要と述べている。抗癌剤治療後も猿死栄 の周辺部は虚血状態となるが，低酸素状態は GLUT の発 現を艺進するため治療直後の評価には注意が必要であ る.

\section{甲状腺癌診断}

最近，PET 癌検診や他領域の癌の検查の結果で甲状腺 癌が疑われ，精査のためにわれわれ耳鼻咽喉科医へ紹介 されることが増加している。糖代謝が一般に巟進してい ない甲状腺分化癌ではFDGの集積がみられないことも 多く，逆に良性甲状腺腫瘍に集積を認めることもあるた め FDG-PET 単独での良悪性の判断は困難と考えられて いる.

われわれは，限局性の強い集積を認めたことから甲状 腺癌を疑わ扎受診にいたった 17 例，20病変について検 討した。全例にエコーで甲状腺腫瘍が確認され，FNA で 10 病変が甲状腺乳頭癌と診断された。以上から，このよ
うな症例にはエコーとFNAによる精査を努めて行うべき であると結論した。

甲状腺癌の再発・転移の検索には ${ }^{201} \mathrm{Tl},{ }^{131} \mathrm{I}$ シンチが用 いられてきたが，FDG-PETとの有用性に関して定まっ た見解はない.Feine ら ${ }^{3)}$ は血中サイログロブリンが高值 のため再発・転移が疑われ，131Iシンチが陰性を示す甲状 腺分化癌を対象に FDG-PET を行い，転移巣の検出率 94 \%と良好な結果を報告している。また，原発・転移巣吕 131IシンチとPETで相反する結果, (1) ${ }^{131}$ I高集積＋FDG 低 集積,または(2) ${ }^{131}$ 集積陰性＋FDG 高集積を示す flip-flap 現象を報告している。この現象は癌の分化度が関連し， 高分化型では ${ }^{131}$ 唯集積，低分化型では FDG が集積する 傾向があるため生じると考元られている。

\section{参考文献}

1) Kostakoglu L, Coleman M, Leonard JP, et al. : PET predicts prognosis after 1 cycle of chemotherapy in aggressive lymphoma and Hodgkin's disease. J Nucl Med 43 : 1018 1030, 2002

2) Haberkorn U, Strasuss LG, Dimitrakopoulou A, et al. : PET studies of fluorodeoxyglucose metabolism in patients with recurrent colorectal tumors receiving reditherapy. J Nucl Med $32: 1485 \sim 1490,1991$

3) Feine U, Lietzenmayer R, Hanke JP, et al. : Fluorine-18-FDG and Iodine-131-iodine uptake in thyroid cancer. J Nucl Med 37 : $1468 \sim 1472,1996$. 